\title{
排砂促進板による粒子輸送特性
}

\section{Characteristics of Particles Transport by Discharging Plate}

\author{
O学 松元 俊二（鹿児島大）
}

\author{
正 野㠃 勉（鹿児島大） 正 福原 稔（鹿児島大） \\ Shunji MATSUMOTO, Kagoshima University, 21-40 Koorimoto 1chome, Kagoshima \\ Tsutomu NOZAKI, Kagoshima University \\ Minoru FUKUHARA, Kagoshima University
}

Key Words: Two-phase flow, Scour, Tractive force, Submarged jet

\section{1. まえがき}

河川，港湾，ダム及び湖沼においては沈皘した砂泥を浚 渫し，管路による浚渫泥の埋立地への水力輸送が行われて きた。この輸送には大量の水を使用するスラリー輸送が用 いられるが，管路の底に沈積した浚渫泥は高粘性であるた め輸送効率は非常に悪くなる ${ }^{(1)}$. 本研究では固体粒子の水 力輸送における高効率化を目指し，管路内に排砂促進板な る板（以下，促進板という，）を設置し促進板下部に発生 する洗掘現象により堆積砂泥を下流方向へと輸送すること を提案した ${ }^{(2)}$. 洗掘現象とは，水理構造物近傍に起こる流 水の作用により河床が削られる現象であり，これまで洗掘 の防止軽減を目指した研究が行われてきた ${ }^{(3)(4)}$. 本研究に おいては,この現象を積極的に利用して沈積砂泥の輸送を 行うことを目的としている. 管路内の砂泥面近傍に促進板 を設け，この促進板と砂泥沈積層との距䧹である初期隙間 bっから発生する噴流による掃流力によって粒子を下流へ輸 送するものである、本実験では、沈積粒子に用いる球形ガ ラスビーズの粒子径や $b_{o}$ をそれぞれ変化させて二次元的 に可視化を行い, 促進板の効果と粒子径による輸送特性に ついて実験的に明らかにした。

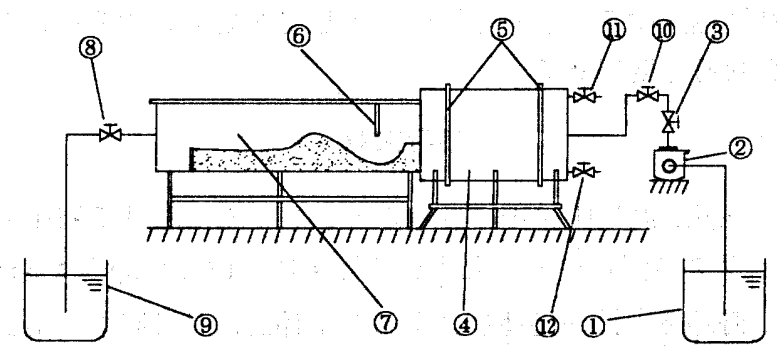

(1) Flow tank for injection (7) Test vessel (2) Main pump (3) On-Off valve (4) Surge tank (5) Honeycomb plate (6) Discharging plate (8) On-Off valve (9) Flow tank for suction (10) Flow control valve (11) Air venting valve (12) Drain valve

\section{2. 実験装直および方法}

Fig.1 に実験装置概略図を示す。流量 $Q$ の設定は促進板 の影響を受けない上流部で沈積面の移動がない条件を選ん だ. 促進板上流面を $\boldsymbol{x}=0$ および粒子沈積層表面を $y=0$ と し，それぞれ水平下流方向および鉛值方向にそれぞれ $x$ 軸 および $y$ 軸をとる. 水たたきのない水平な粒子沈積面に対して 鉛直に置かれた促進板と粒子沈積面との隙間に形成される開口部 を流れるいわゆる潜り噴流の掃流力によって，沈積面表面の粒子 は下流一と輸送される. その際，促進板上流側の板近傍では近寄 り速度による粒子輸送が生じ，促進板直下の開口幅が時間ととも に変化する点が, 従来の水門で見られる潜り噴流による砂泥輸送 とは異なるところである. 以下に述べる結果は, 粒子輸送開始淔 後, 初期隙間 $b_{o}$ を通過する流量を $Q=10.8 \times 10^{2} \mathrm{~m}^{3} / \mathrm{min}$ とし, 沈皘 粒子の平均粒子径 $d_{p}=47 \mu \mathrm{m}, 171 \mu \mathrm{m}, 261 \mu \mathrm{m}, 519 \mu \mathrm{m}$ 及び $1015 \mu \mathrm{m}$ に つい $b_{o}=0.5 \times 10^{2} \mathrm{~m}$ 及び $1.0 \times 10^{2} \mathrm{~m}$ と変化させた.

\section{3. 実験結果および考察}

Fig.2 に $b_{o}=0.5 \times 10^{-2} \mathrm{~m}$ における $d_{p}=47 \mu \mathrm{m}, 171 \mu \mathrm{m}, 261$ $\mu \mathrm{m}$ 及び $519 \mu \mathrm{m}$ の $t=2.0 \mathrm{sec}$ の可視化画像を示す.

粒子輸送開始直後, 促進板直下の粒子沈積面が局所的に 強い掃流力を受け，深さ及び下流方向の洗掘が進行するが, やがて速度減衰に伴う掃流力の低下とともに粒子は下流に 堆積する. $d_{p}=47 \mu \mathrm{m}$ において粒子輸送は沈積層の表層部 を削り取る程度のものである。これは粒子径が小さいため 粒子当りに働く掃流力が小さくなることと, 単位体積当り 粒子接触点数の增加による粒子粘性が大きくなるためと考 えられる. $d_{p}=519 \mu \mathrm{m}$ において下流側に高さ方向への浮遊 粒子が確認できる。これは洗掘が深さ方向に顕著であった ため、湾曲した粒子移動床に沿った水流が高さ方向へ向か ったものと考えられる。Fig.3に $b_{o}=0.5 \times 10^{-2} \mathrm{~m}$ における最 大洗掘深さ $y_{\text {max }}$ の時間変化を示す. 縦軸は最大洗掘深さ $y_{\max }$ をそれぞれの初期隙間 $b_{o}$ で無次元化した深さ方向距離 であり，横軸は時間 $t$ である. $d_{p}=261 \mu \mathrm{m}, 519 \mu \mathrm{m}$ 及び 1015 $\mu \mathrm{m}$ において哚さ方向への洗掘が顕著に見られるのは輸送 開始直後から $t=2.0 \mathrm{sec}$ であり, その後は哚さ方向への洗掘 と埋め戻しを繰り返しながら緩やかに進行していくことが 分かる.これは開口部が大きくなるにつれ開口部を通過す る水流の速度減衰に伴う掃流力の低下と，深さ方向への洗 


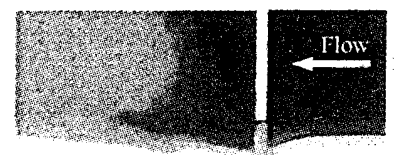

$t=2 \mathrm{sec}$

(a) $d_{p}=47 \mu \mathrm{m}$

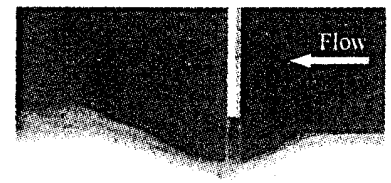

$t=2 \sec$

(c) $d_{p}=261 \mu \mathrm{m}$

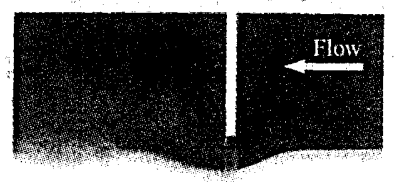

$t=2 \sec$

(b) $d_{p}=171 \mu \mathrm{m}$

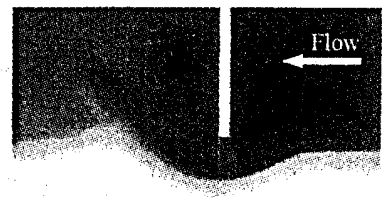

$t=2 \mathrm{sec}$

(d) $d_{p}=519 \mu \mathrm{m}$
Fig.2 Visualization of transported particles

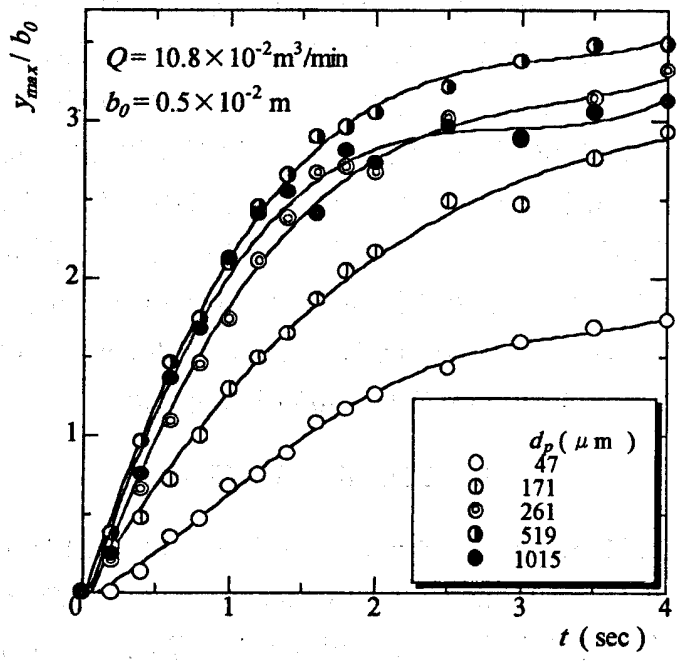

Fig.3 Variation of maximum scoured depth with time

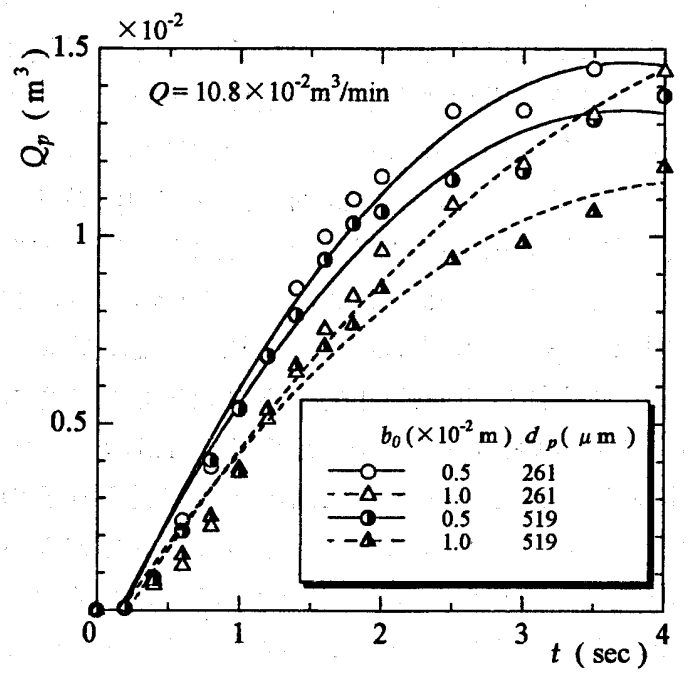

掘の発達により粒子移動床の勾配が急になり粒子は自重に よる崩落を始め, 結果として埋め戻しが起こったことによ るものと考えられる

Fig.4 は $d_{p}=261 \mu \mathrm{m}$ 及び $519 \mu \mathrm{m}$ について $b_{o}=0.5 \times 10^{-2} \mathrm{~m}$ 及ひ $b_{o}=1.0 \times 10^{-2} \mathrm{~m}$ における粒子輸送量 $Q_{p}$ の時間峦化を 示している. $d_{p}=261 \mu \mathrm{m}$ について $b_{o}=0.5 \times 10^{-2} \mathrm{~m}$ 及び $b_{o}=$ $1.0 \times 10^{-2} \mathrm{~m}$ を比較すると, $b_{o}=0.5 \times 10^{-2} \mathrm{~m}$ の場合, 輸送開 始直後から $t=2.0 \mathrm{sec}$ まで $Q_{p}$ は単調に増加しているが, $t=2.0 \mathrm{sec}$ 以降は埋め戻しの影響を受けるため, 増加率は軽 減される。これに対して $b_{o}=1.0 \times 10^{-2} \mathrm{~m}$ の場合は輸送開始 直後から $た 4.0 \mathrm{sec}$ まで $Q_{p}$ は単調に増加しているおり， $t=4.0 \mathrm{sec}$ では $b_{o}=0.5 \times 10^{-2} \mathrm{~m}$ の場合とほぼ同じ值を示すま で増加している.これは $b_{o}=0.5 \times 10^{-2} \mathrm{~m}$ において洗掘が染 さ方向に支配的なため埋め戻しの影響を受けやすくなった のに対して， $b_{o}=1.0 \times 10^{-2} \mathrm{~m}$ においては，洗掘が下流方向 に支配的であったため粒子の崩落を起こさない程度になだ らかな粒子輸送形状であったためと考えられる．実用上， 複数の促進板による連続的な粒子輸送 ${ }^{(5)}$ において排砂促 進板の効果を必要とするのは輸送開始直後からた2.0sec 程 度までであることを考えると, 粒子の崩落はさほど問題で はない。

\section{4. むすひ}

管路輸送における排砂促進板による粒子輸送の実用化を 目指す上で，粒子沈積層近傍に設置された排砂促進板によ り粒子がどのように輸送されるかを，単一促進板について 実験した.いずれの粒子径においても粒子輸送開始直後, 流速の速い促進板直下から流体の掃流力による洗掘が生じ, 粒子沈積層は大きく変形し, 粒子は下流入と輸送されるが, やがて流速の減衰とともに，掃流力は低下し，粒子は下流 部に堆積する.しかし、粒子径によって輸送形状や輸送量 は異なり，排砂促進板による粒子輸送を効果的に行うため には被輸送粒子の粒径や性状に応じて初期隙間や流量を変 化させる必要がある.

\section{参考文献}

(1) 西川, 混気圧送浚渫泥輸送のシステムにおける液相ス ラグの流動現象, 混相流 7 巻 4 号 (1993) pp.335-343

（2）野㟝ら，排砂促進板による粒子輸送, 混相流学会年会 講演会 2001 講演論文集 pp.223-224

（3）土屋, 滑面水路床の下流端における洗掘限界, 土木学 会論文集第 80 号（昭.37.4）pp.18-27

（4）土屋, 水門下流部における洗掘限界に関する研究, 土 木学会論文集第 82 号（昭.37.6）pp.21-49

(5) 野㟝ら, 排砂促進板による粒子輸送の可視化, 可視化 情報 Vol.21 Suppl. No.1 pp.89-92

Fig.4 Variation of scoured volume with time 